\title{
AN ABNORMAL DISPOSITION OF THE PULMONARY VEINS
}

\author{
BY \\ H. BUTLER \\ From the Department of Anatomy, St. Bartholomew's Hospital Medical College, London
}

(RECEIVED FOR PUBLICATION DECEMBER 10, 1951)

The entrance of the pulmonary veins into the right atrium or into the systemic veins is sufficiently uncommon, but rarer still is their entrance into the portal venous system. Since the first example of abnormal disposition of the pulmonary veins was described by Winslow in 1739 the literature revieals reports of 138 instances confirmed at necropsy (Brody, 1942; Hughes and Rumore, 1944 ; Brantigan, 1947 ; Young, 1947 ; Edwards and DuShane, 1950 ; Edwards, DuShane, Alcott, and Burchell, 1951 ; Smith, 1951). Recently additional examples have been diagnosed by angiocardiography and cardiac catheterization (Welti and Nedey, 1950 ; Hwang, Prec, Kuramoto, Segall, and Katz, 1950 ; Runström and Sigroth, 1950 ; Grishman, Brahms, Gordon, and King, 1951), but because they lack direct anatomical confirmation they are not here considered further. While anomalies of the systemic veins are notoriously frequent, recorded anomalies of the pulmonary veins are remarkably few. It will be shown here that the mode of development of the pulmonary vein is such that the incidence of its anomalies might be expected to exceed that recorded.

Twelve of the 138 anatomically confirmed examples showed abnormal pulmonary veins which entered, totally or partially, the portal venous system. In eight such instances the pulmonary veins drained into the stem of the portal vein (Ramsbotham, 1829 ; Bochdalek, 1858; Geipel, 1899 ; Hu, 1929; Munck, 1933 ; Terplan and Sanes, 1936 ; Young, 1947 ; Mykschowszky, 1948) ; in three instances they drained into the left branch of the portal vein via the still patent ductus venosus (Ghon, 1916; Mehn and Hirsch, 1947 ; Edwards and DuShane, 1950); in Arnold's (1868) specimen, of intermediate type, the pulmonary veins were connected to the obliterated ductus venosus, the left branch of the portal vein, the stem of the portal vein, and directly to the intrahepatic veins of the quadrate hepatic lobe. The personal specimen described below is an example of a common pulmonary vein joining the left branch of the portal vein close to the beginning of the ductus venosus.

\section{Summary of the Case History}

A second child, born at 9.15 p.m. on January 25 , 1951, after an uneventful pregnancy, appeared to be normal, but became pale and collapsed three and a half hours later. After extraction of mucus and the administration of oxygen some colour returned, but the child remained cyanosed until his sudden death at 6.45 p.m. on January 26 -that is, $45 \frac{1}{2}$ hours after birth.

\section{POST-MORTEM REPORT}

The body is that of a moderately well nourished newborn male infant with conspicuous cyanosis, particularly of the extremities.

The lungs are poorly aerated, but apart from the generalized congestion of the various organs, the only abnormalities present are those of the pulmonary veins and of the left side of the heart.

Three pulmonary veins issue from the right lung and two from the left: these join to form, respectively, short, wide right and left pulmonary veins lying on the anterior aspect of the oesophagus outside the pericardium. The right and left pulmonary veins immediately unite into a common pulmonary vein, $2.5 \mathrm{~cm}$. long and $4.0 \mathrm{~mm}$. in diameter, lying on the oesophagus close to the right vagus nerve (Fig. 1). This common pulmonary vein runs caudally, just to

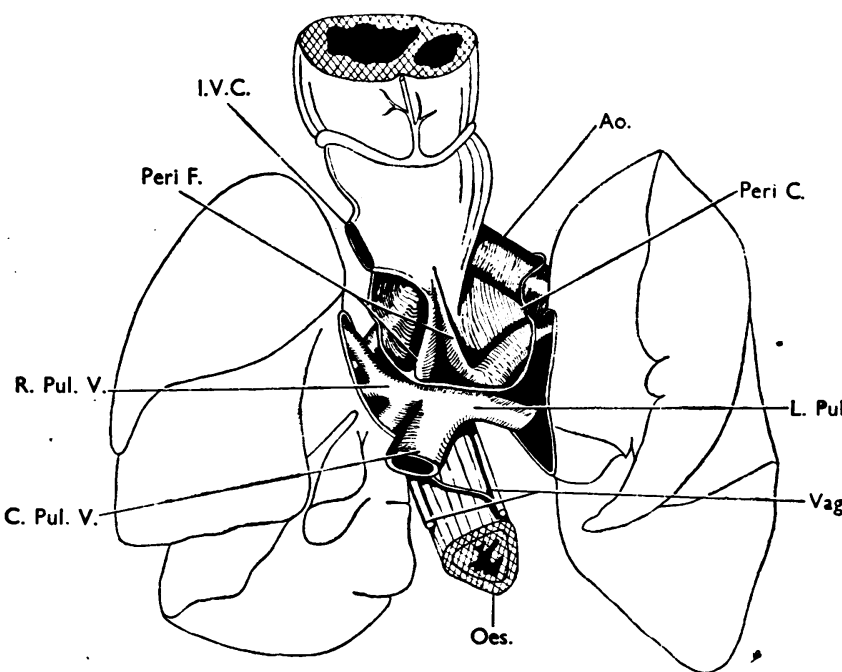

FIG. 1.-Drawing of the heart, lungs, and oesophagus showing the common pulmonary vein and the abnormal intrapericardial folds. For key, see Fig. 6. 


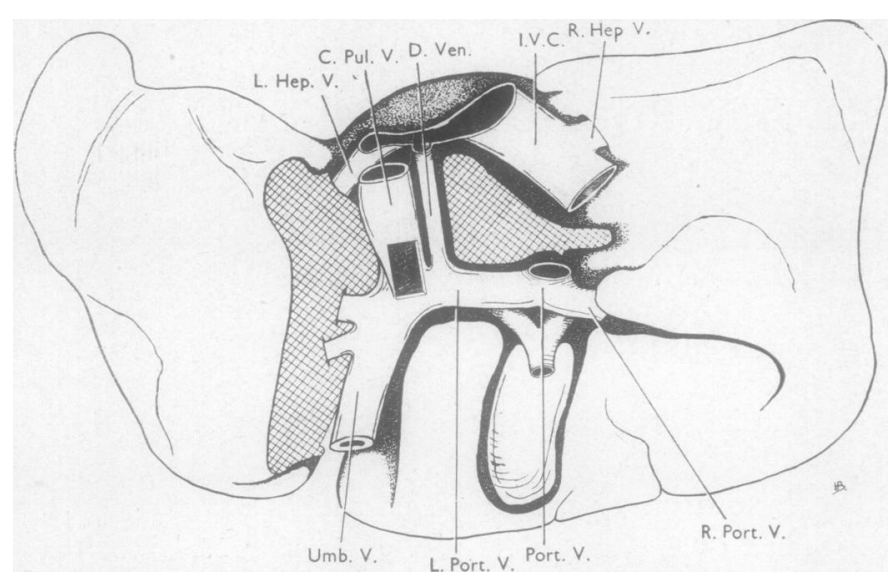

FIG. 2.-Drawing of the liver as seen from below and behind showing the termination of the common pulmonary vein. A window has been cut in the terminal part of the common pulmonary vein to show the site of the stenosis due to the proliferating connective tissue. The caudate
hepatic lobes have been removed. For key, see Fig. 6 .

the left of the midline, to pierce the diaphragm through an adventitious foramen situated, between the oesophageal and caval foramina. It then runs in the left triangular ligament, passing immediately posterior to the left hepatic vein to run in the groove between the hepatic caudate and sinistral lobes. Here it lies parallel to, and to the left of, the still-patent ductus venosus. It terminates in the left branch of the portal vein, by a narrow orifice, immediately to the left of the ductus venosus and almost opposite the still-patent intra-abdominal umbilical vein (Fig. 2). The narrowing of its terminal orifice, which is less than $1.0 \mathrm{~mm}$. in diameter, is due to thickening of the vessel wall.

The " $T$ "-shaped vessel formed by the right, left, and common pulmonary veins is closely applied to the exterior of the fibrous pericardium immediately caudal to the base of the heart. Within the pericardial cavity appear two crescentic folds of the serous pericardium. These begin on the uppermost part of the dorsal wall of the pericardial sac at the level of the right and left pulmonary veins, cross the line of the pericardial reflection, and thereafter run on to the posterior surface of the left atrium. Here they run caudally, gradually approaching each other, to fade away at the level of the junction of the inferior vena cava and right atrium (Fig. 1). Owing to the absence of the intra pericardial parts of the pulmonary veins the oblique sinus is only imperfectly formed, and these foles form its incomplete left boundary. The right fofid is avascular, but the left contains a leash of sm 1 veins connecting the left upper pulmonary vein to the left atrium. These small veins and the Thebesifh veins are the only vessels entering the left atriu apart from the via sinistra of the inferior vena cava.

The respective capacities of the left atrium and ventricle are estimated to be less than half those their right counterparts. There is little difference thickness of wall between the right and left cardiac chambers, but the left ventricular wall is very slightiy the thinner. The aorta, pulmonary arteries, and vente cavae are normal: the foramen ovale is patent bet valvular.

The distal end of the common pulmonary vein and the ductus venosus were serially sectioned at $10 \mathrm{cs}$, and alternate slides were stained with Weigert-V Se Gieson's stain and with haematoxylin and eos Examination showed the last $3 \mathrm{~mm}$. of the comm pulmonary vein to be narrowed by the ingrowth of a mass of newly formed, vascular, connective tissue most prolific at the termination of the vein, whof lumen was thereby reduced to a diameter of less than $1 \mathrm{~mm}$. About $1 \mathrm{~mm}$. from the vein mouth the amount of newly formed connective tissue decrease्e d

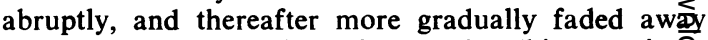
to end some $3 \mathrm{~mm}$. along the vessel. This new tiss fe consisted of fibroblasts with large, elongated, vesiç lar nuclei, a number of which were undergoing mitomc division. The ground substance showed no rë coloration with van Gieson's stain. Scattered amoझg the fibroblasts were a few small, irregularly arranged elastic fibres and an occasional plasma cell. The we्तु

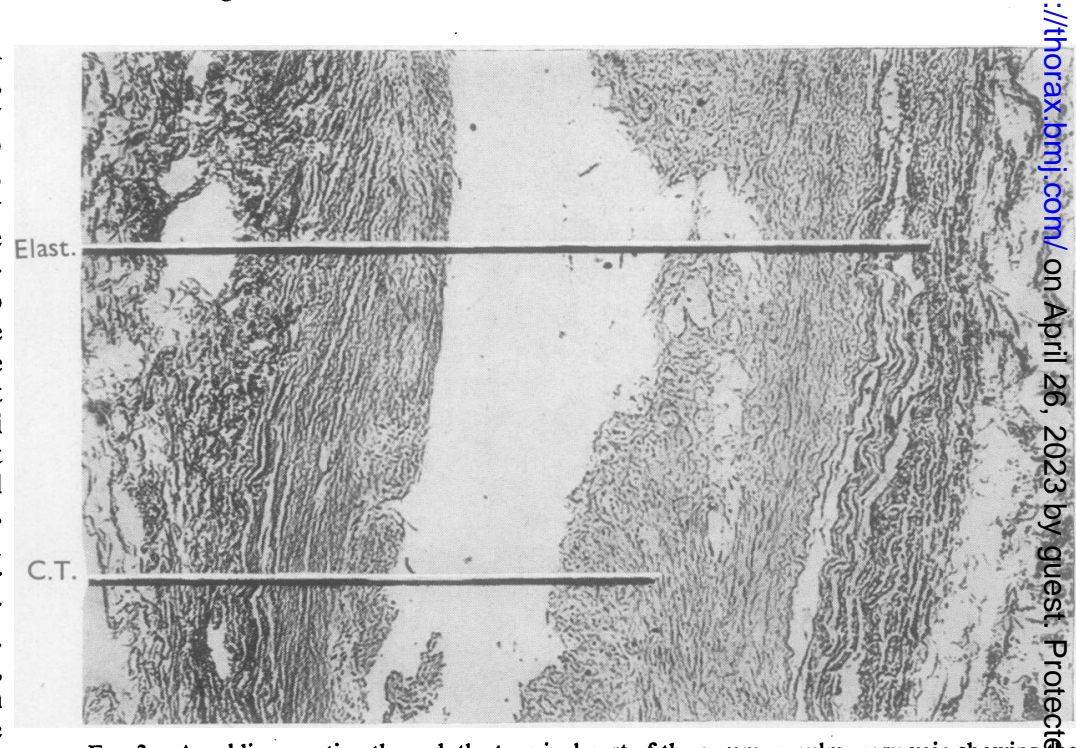

FIG. 3.-An oblique section through the terminal part of the common pulmonary vein showing $\overrightarrow{\mathbb{A}_{\mathrm{g}}}$ proliferating connective tissue encroaching on the vessel lumen. Weigert-van Giesoli's stain, $\times$ 50. For key, see Fig. 6. 
of the common pulmonary vein was $900 \mu$ thick and consisted of collagen fibres, longitudinal smooth muscle, and numerous coarse elastic fibres (Figs. 3 and 4).

The ductus venosus wall was thinner $(480 \mu)$, and consisted mainly of collagen fibres with some coarse elastic fibres and a few longitudinal smooth muscle fibres. It, too, was undergoing initial obliteration throughout its entire length by newly formed vascular connective tissue, precisely similar to that within the common pulmonary vein. This adventitious connective tissue was most abundant at the site of union with the portal vein. Similar, but much less abundant, tissue was found in the terminal part of the intra-abdominal umbili-

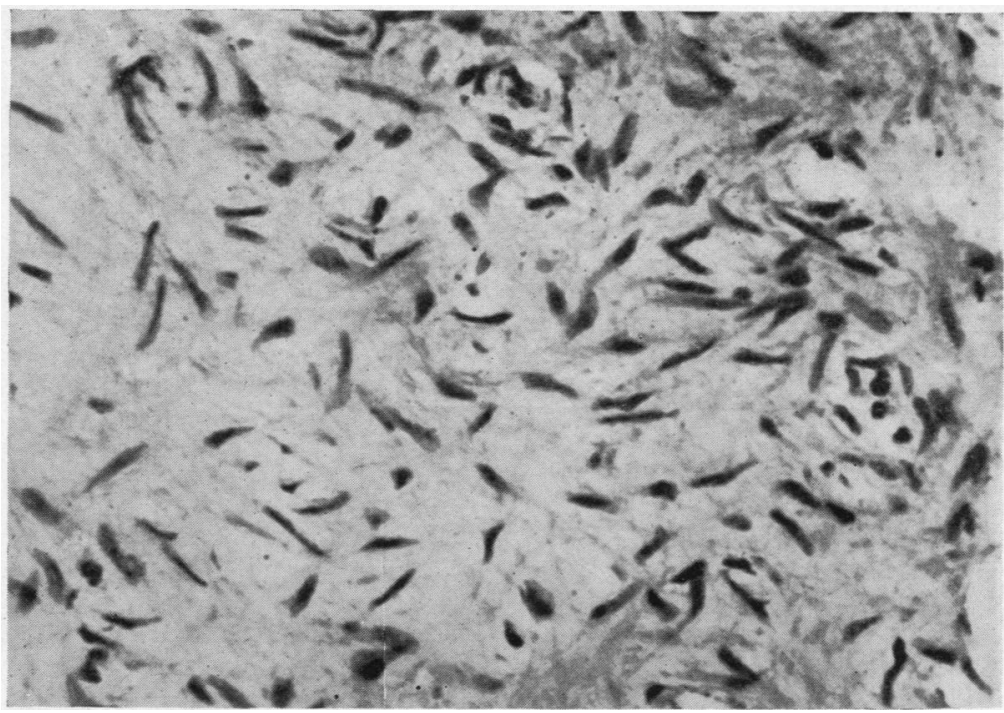

FIG. 4.-A high-power view of the newly formed, vascular connective tissue. Haematoxylin and eosin, $\times 360$. cal vein.

Liver sections showed congestion of the sinusoids and the presence of large fat globules within the hepatic cells.

\section{Discussion}

The specimen described above closely resembles those recorded by Ghon (1916), Mehn and Hirsch (1947), and Edwards and DuShane (1950), and constitutes the fourth known example of this particularly rare venous anomaly. Two types of

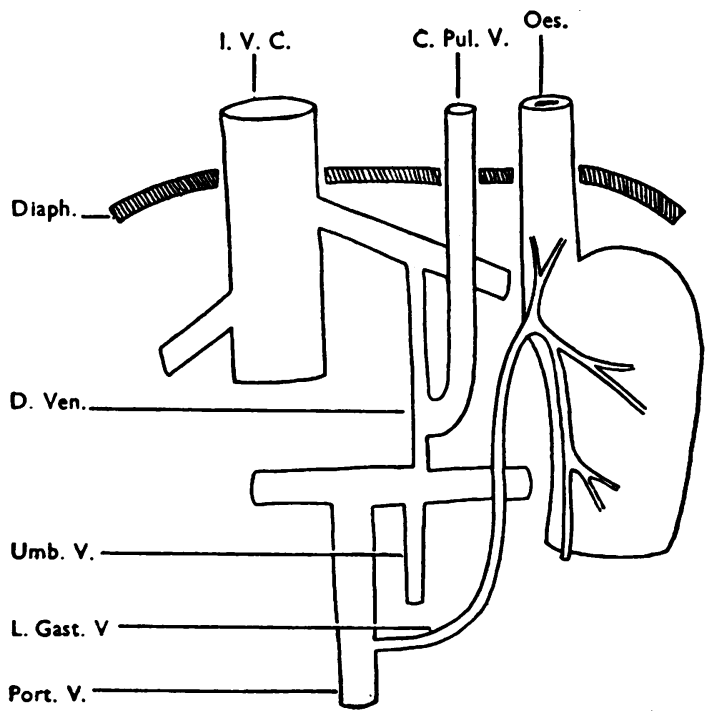

TYPE A anomalous entrance of the pulmonary veins into the portal venous system can be recognized (Fig. 5). Type $\mathbf{A}$ includes the above-mentioned cases and is characterized by the union of all the pulmonary veins into a single common pulmonary vein which runs caudally, in close contact with the ossophagus, and generally perforates the diaphragm through an adventitious foramen situated between the oesophageal and caval foramina, but exceptionally (Edwards and DuShane, 1950) traversing the oesophageal hiatus. Below

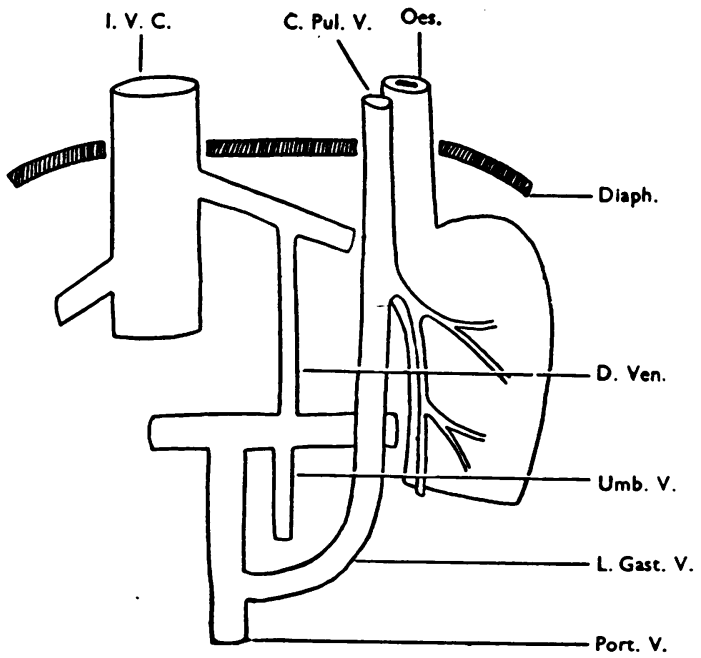

TYPE B

FIG. 5.-Diagram to illustrate the two types of pulmo-portal venous anomalies. For key, see Fig. 6. 
the diaphragm the common pulmonary vein runs in the groove on the left side of the hepatic caudate lobe to join the left branch of the portal vein, via, or close to, the still-patent ductus venosus. Clinically, all patients suffering from this disability manifest cyanosis and die early (Table I). Only

TABLE I

Pulmo-portal Venous anomalies Type A

\begin{tabular}{|c|c|c|}
\hline Author & $\begin{array}{l}\text { Age at } \\
\text { Death }\end{array}$ & $\begin{array}{l}\text { Associated Major } \\
\text { Cardiac Anomaly }\end{array}$ \\
\hline $\begin{array}{l}\text { Ghon }(1916) \\
\text { Mehn and Hirsch }(1947) \\
\text { Edwards and DuShane }(1950) \\
\text { Present case .. }\end{array}$ & $\begin{array}{l}15 \text { days } \\
12,, \\
9, ", \\
451 \text { hurs }\end{array}$ & $\begin{array}{l}\text { None } \\
\text { Coarctation of the aorta } \\
\text { None }\end{array}$ \\
\hline $\begin{array}{llll}\text { Present case } & \ldots & \ldots & \ldots\end{array}$ & $45 \frac{1}{2}$ hours & 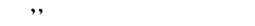 \\
\hline
\end{tabular}

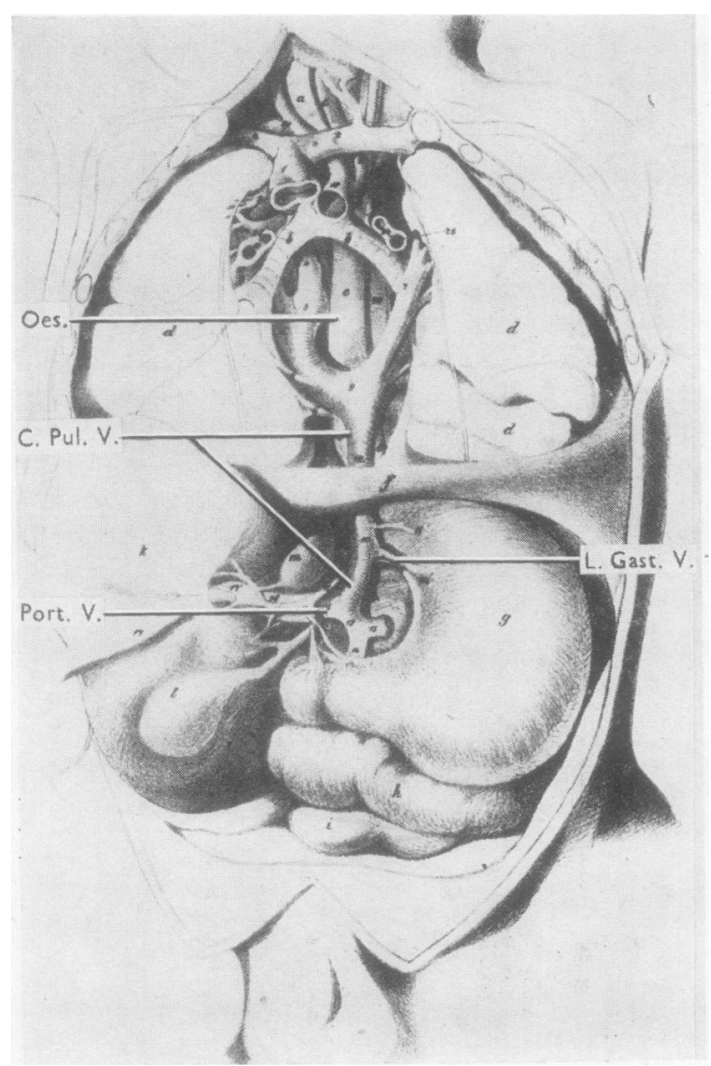

FIG. 6.-A typical example of type B pulmo-portal venous anomaly (reproduced from Bochdalek, 1858).

C.T. = newly forn.ed connective tissue. D.Ven. = ductus venosus. Diaph. = diaphragn.. Elast $=$ elastic tissue in wall of common pulmonary vein. L.Gast.V. = left gastric vein. R.Hep.V. = right hepatic vein. L.Hep.V. = left hepatic vein. I.V.C. = inferior vena cava. Oes. = oesophagus. PeriC. =cut edge of perivena cava. Oes. = oesophagus. PeriC. $=$ cut edge of peri-
cardium. PeriF. = anomalous intrapericardial folds. Port. V. $=$ cardium. PeriF. $=$ anomalous intrapericardial folds. Port. V. $=$
stem of portal vein. R.Port. $V .=$ right branch of portal vein. L.Port.V. = left branch of portal vein. C.Pul.V. = common pulmonary vein. R.Pul.V. = right pulmonary vein. L.Pul.V. = left pulmonary vein. Umb. V. = intra-abdominal umbilical vein. Vag.= vagus nerve. $A o .=$ aorta. one example (Mehn and Hirsch, 1947) showed associated major cardiac anomaly.

Eight recorded examples of anomalous pự monary vein arrangement presented the pattern of a common pulmonary vein running caudally with the oesophagus, and, in five instances, piercing the diaphragm via the oesophageal hiatus (Ramsbotham, 1829; Bochdalek, 1858 ; Geipel, 189\%: Hu, 1929; Munck, 1933; Terplan and Sanes, 1936 ; Young, 1947 ; Mykschowszky, 1948). Sue्र्र a common pulmonary vein joins the stem of the portal vein via the grossly dilated terminal part of the left gastric vein behind the peritoneal posterifor wall of the lesser sac. These examples constitute type B of anomalous pulmo-portal venous arrange ment, which is well illustrated by the specimen described by Bochdalek (1858) (Figs. 5 and 8 ). Patients manifesting type B anomaly suffer from cyanosis and, despite the fact that the majority them present an associated major cardiac anoma\&, live longer than patients with type A anomaty (Table II).

TABLE II

Fulmo-portal Venous anomalies Type B

\begin{tabular}{|c|c|c|c|}
\hline Author & & $\begin{array}{l}\text { Age at } \\
\text { Death }\end{array}$ & $\begin{array}{l}\text { Associated Major } \\
\text { Cardiac Anomaly }\end{array}$ \\
\hline 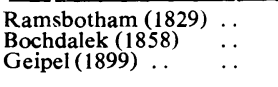 & $\begin{array}{l}\cdots \\
\cdots \\
\cdots\end{array}$ & $\begin{array}{l}6 \text { mths } \\
4 \text { days } \\
\text { 3-6 mths }\end{array}$ & $\begin{array}{l}\text { Cor biloculare } \\
\text { I.V.C. enters both a } \\
\text { R. half of a thoma- }\end{array}$ \\
\hline $\begin{array}{l}\text { Hu (1929) } \\
\text { Munck (1933) } \\
\text { Terplan and Sanes (1936) }\end{array}$ & $\begin{array}{l}\cdots \\
\cdots \\
\cdots\end{array}$ & $\begin{array}{l}7 \\
3 \\
12 \text { hours }\end{array}$ & $\begin{array}{l}\text { Cor triloculare, etc. } \\
\text { None } \\
\text { Cor triloculare biats- } \\
\text { atrium, etc. }\end{array}$ \\
\hline $\begin{array}{l}\text { Young (1947) } \\
\text { Mykschowszky (1948) }\end{array}$ & $\begin{array}{l}\cdots \\
\cdots\end{array}$ & $\begin{array}{l}\text { Born dead } \\
18 \text { days }\end{array}$ & $\begin{array}{l}\text { Cor biloculare } \\
\text { None }\end{array}$ \\
\hline
\end{tabular}

Arnold's (1868) specimen is of considera interest, in that the connexions of the pulmonary vein exhibit features of types A and B and, additionally, direct connexions with the intrahepatic veins of the quadrate lobe. Ramsbotharins (1829) specimen also showed a composite termitation of the pulmonary veins, the right vessels joining the portal vein, the left vessels the left sigsclavian vein.

It seems certain that the pulmonary vein has dual developmental origin, and, on such a hypithesis, an explanation of these anomalies may be offered. Brown (1913) showed in the cat that peripheral part of the pulmonary venous syst develops from that part of the foregut venous plexus surrounding the developing lung buds. The foreght venous plexus develops in situ in the splanchpic mesoderm and drains primarily into the heart fa the vitello-umbilical and cardinal veins. Only $\mathscr{P}$ a relatively late stage $(8 \mathrm{~mm}$. human embr河, 
$5.5 \mathrm{~mm}$. cat and rat embryos) does it acquire an independent and direct route into the heart by a single pulmonary vein running in the caudal part of the dorsal mesocardium. Brown (1913) believed that this connexion with the heart is due to the forward growth of the lung bud bringing the pulmonary part of the foregut venous plexus into contact with the heart. Later investigators (Buell, 1922 ; Schornstein, 1931 ; Chang, 1931 ; Streeter, 1945 ; Auër, 1948 ; Butler, 1952) have shown that an endothelial outgrowth from the dorsal wall of the sinu-atrial chamber of the heart unites with one of the capillaries of the pulmonary part of the foregut venous plexus. Federow (1910) first described this endothelial outgrowth from the heart, but he believed that it gave rise to the whole of the pulmonary venous system and not merely to the stem of the pulmonary vein. Should this union fail, pulmonary venous outflow must, in order to maintain the circulation, reach the heart by alternative routes such as are readily available in the primary drainage routes of the foregut venous plexus (i.e., the cardinal and vitelloumbilical veins). Thus, in the absence of a normal pulmonary vein, the pulmonary venous blood returns to the heart via the systemic or the portal venous systems, including the ductus venosus. Examples of all types of such anomalous venous return have been described, but those utilizing the portal venous system are the most uncommon, particularly those taking advantage of the ductus venosus.

At an early stage the foregut venous plexus forms well-marked, longitudinal channels grouped around the vagus nerves, the perivagal veins (Butler, 1952) which receive blood from the oesophagus and from the lung buds and drain into the cardinal and vitello-umbilical veins; the close association of the common pulmonary vein with the vagus nerves in the case here described strongly suggests that these perivagal veins are utilized to form the abnormal common pulmonary vein. Further, in the human adult, the most caudal perivagal veins are the oesophageal tributaries of the left gastric vein (Butler, 1951) which enter the left gastric vein at the beginning of its retro-peritoneal portion, i.e., where the common pulmonary vein joins the dilated left gastric vein in examples of type $B$. In the adult rat the perivagal veins establish a direct connexion between the left gastric vein and the pulmonary veins (Butler, 1952), and similar, but indirect, connexions have bèen shown in man (Zuckerkandl, 1882 ; Konaschko, 1929). It is also noteworthy that, in a number of specimens, the anomalous common pulmonary vein traverses the oesophageal hiatus.

Little information is available regarding the details of ductus venosus development, the ductus being usually regarded as a derivative of the hepatic sinusoids. In the early stage of development the peri-gastric part of the foregut venous plexus has direct connexions with the hepatic sinusoids (Butler, 1952), and such connexions may be the means whereby an anomalous common pulmonary vein may establish communication with the ductus venosus. Such a view is supported by Arnold's (1868) specimen which combined features of types $A$ and $B$ in that the common pulmonary vein joined both the portal vein and the ductus venosus and had, additionally, direct communication with the intra-hepatic veins. In some instances the abnormal common pulmonary vein pierces the diaphragm by a separate foramen situated in much the same position as the left venous foramen of Blair (1923). Frequently Blair's foramen transmits a vein connecting the oesophageal veins to the left hepatic vein and thus, indirectly, with the ductus venosus. Blair (1923) regarded this anastomotic vein as the remnant of the suprahepatic part of the vitello-umbilical veins. It may well play a part in the formation of anomalous pulmonary veins of the pattern described here. Ramsbotham's (1829) specimen is of interest in showing the pulmonary venous return utilizing both primary drainage routes of the pulmonary part of the foregut venous plexus, that is, systemic and portal veins, in the absence of a direct pulmonary venous connexion with the left side of the heart. Thus, all the potential routes for the pulmonary venous return demonstrable in the embryo and adult may be utilized, singly or in combination, when the pulmonary vein outgrowth fails to join the future pulmonary venous plexus. In the specimen described here the small veins in the pericardial folds bounding the maldeveloped oblique sinus may represent an abortive attempt to form the stem of a normal pulmonary vein. It is not possible to advance any plausible hypothesis for the failure of union of the pulmonary vein outgrowth with the pulmonary venous plexus, but such a developmental error might reasonably be expected to provide the basis for frequent anomalies of pulmonary venous pattern.

The diversion of the pulmonary venous blood from the left side of the heart does not appear to affect the development of the embryo except in so far as the reduced blood volume entering the left atrium leads to a diminution of atrial capacity which in turn reduces left ventricular capacity. 
Such diversion is not necessarily associated with other major cardiac anomalies and its effect becomes apparent only after birth. The diversion of the oxygenated blood leads to cyanosis and, if complete, to early death (Brody, 1942).

A striking feature of the present specimen is the presence of proliferating connective tissue in the terminal part of the abnormal common pulmonary vein. This tissue is identical with that responsible for the post-natal obliteration of the ductus venosus and of the intra-abdominal umbilical vein, while similar tissue is also found in the obliterating ductus arteriosus. Its presence in the common pulmonary vein suggests that the terminal segment of this vein was, in fact, a part of the ductus venosus or that the obliterative process had spread from the ductus venosus. This terminal stenosis must have seriously impeded the pulmonary venous return and may well have been partly responsible for the early death of the infant. Reference to Tables I and II shows that life is considerably shorter in those patients in whom the abnormal common pulmonary vein opens into the ductus venosus, despite the fact that type B cases show a higher proportion of associated major cardiac anomalies. Early obliteration of the terminal segment of the abnormal common pulmonary vein, as described above, may account for this difference.

\section{SUMmaRY}

A specimen, the fourth to be recorded, is described of an anomalous common pulmonary vein draining into the left branch of the portal vein, close to the beginning of the ductus venosus.

An embryological explanation, based on the hypothesis of dual developmental origin of the pulmonary vein, that is, from the heart and the foregut venous plexus, is submitted.

The terminal part of the anomalous common pulmonary vein was almost completely obliterated by proliferating connective tissue such as is normally responsible for the obliteration of the ductus venosus.
An attempt is made to classify the recorde examples of pulmo-portal venous anomalies.

My thanks are accorded to Dr. A. M. Barrett, of the Department of Pathology, University of Cambridge, both for the presentation of this specimen and $f \mathscr{P}_{\mathrm{r}}$ permitting its publication, and to Professor A. J. E. Cave for assistance in the preparation of this paper. To the departmental technicians, Miss J. Stedman a $\overrightarrow{0 d}$ Mr. A. E. Westwood, are due respectively the sections and the photomicrographs.

\section{REFERENCES}

Arnold, J. (1868). Virchows Arch., 42, 449.

Auër, J. (1948). Anat. Rec., 101, 581.

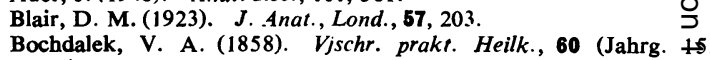
4), 160.

Brantigan, O. C. (1947). Surg. Gynec. Obstet., 84, 653.

Brody, H. (1942). Arch. Path., Chicago, 33, 221.

Brown, A. J. (1913). Anat. Rec., 7, 299.

Buell, C. E. (1922). Contr. Embryol. Carneg. Instn (No. 66), 14,

Butler, H.(1951). Thorax, 6, 276.

- (1952). J. Anat., Lond., 86, 95.

Chang, C. (1931). Anat. Rec., 50, 1. 49, 517.

$-\frac{1}{446}$ Alcott, D. L., and Burchell, H. B. (1951). Ibid., ¿1,

Federow, V. (1910). Arb. Anat. Inst., Wiesbaden, 40, 529.

Geipel, P. (1899). Festschr. Fürfzigjühren Bestehen des Staatkran赑nhauses zu Dresden. Quoted by Ghon, 1916.

Ghon, A. (1916). Beitr. path. Anat., 62, 175.

Grishman, A., Brahms, S. A., Gordon, A., and King, F. H. (19\$1 J. Mt Sinai Hosp., 17, 336.

Hu, C. H. (1929). Amer. J. Path., 5, 389.
Hughes, C. W., and Rumore, P. C. (1944). Arch. Path., Chic $\overrightarrow{\vec{B}}_{\mathrm{g}}$,

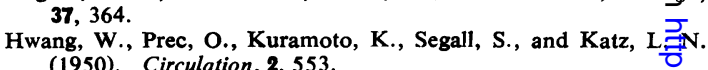
(1950). Circulation, 2, 553.

Konaschko, P. I. (1929). Z. Anat. EntwGesch., 89, 672.

Mehn, W. H., and Hirsch, F. E. (1947). Amer. J. Path., 23, 125.

Munck, W. (1933). Acta path. microbiol. Scand., 10, 447 (erroneously numbered 321).

Mykschowszky, G. (1948). Klin. Med., Wien, 3, 263.
Ramsbotham, F. (1829). London med. phys. J., 61 (n.s. 6), 548.

Runström, G., and Sigroth, K. (1950). Acta. med. scand., Sựpl. 246, p. 176.

Schornstein, T. (1931). Morph. Jb., 67, 566.

Smith, J. C. (1951). Amer. Heart J., 41, 561.

Streeter, G. L. (1945). Contr. Embryol. Carneg. Instn (No. Q9), 31, 29.

Terplan, K., and Sanes, S. (1936). J. tech. Methods, 15, 86 Welti, J. J., and Nedey, R. (1950). Arch. Mal. Cour, 43, 464.

Winslow, J. B. (1739). Quoted by Brody (1942).

Young, M. O. (1947). Arch. Path., Chicago, 44, 169.

Zuckerkandl, E. (1882). S.B. Akad. Wiss. Wien, 84, (abt. 3), 110

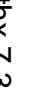

